\title{
CAUSES AND EFFECTS OF ADVERSE EVENTS DURING WATER SUPPLY AND SEWERAGE SYSTEM CONSTRUCTIONS
}

\author{
I. RYBKA ${ }^{1}$, E. BONDAR - NOWAKOWSKA ${ }^{2}$, M. POLOŃSKI ${ }^{3}$
}

\begin{abstract}
This paper identifies the adverse events occurring during the execution of water supply and sewerage systems construction. The basis for this paper is research conducted in 2010-2014 on the construction sites of water supply and sewerage systems located in the provinces of Lower Silesia and Opole. The research consisted of direct observations of construction sites and review of construction documentation. It showed that work stoppages on the examined construction sites were frequent. They were caused by violations of work discipline by the production employees, adverse weather conditions, and defects in the project documentation. The study demonstrated that in almost every case, these had an adverse effect on the completion date and budget of the investment. The analyses show that in such important and expensive investments as water supply and sewerage systems, organizational structures in which a special role is assigned to middle-rank personnel should be adopted.
\end{abstract}

Keywords: water supply systems, sewerage systems, work stoppages

\footnotetext{
' PhD., Eng., Wrocław University of Environmental and Life Sciences, Faculty of Environmental Engineering and Geodesy, ul. C. K. Norwida 25, 50-375 Wrocław, Poland, e-mail: i.rybka@biuroinwestorskie.pl

${ }^{2}$ Associate professor, DSc., PhD., Eng., Wrocław University of Environmental and Life Sciences, Faculty of Environmental Engineering and Geodesy, ul. C. K. Norwida 25, 50-375 Wrocław, Poland, e-mail: elzbieta.bondar-nowakowska@up.wroc.pl

${ }^{3}$ Associate professor, DSc., PhD., Eng., Warsaw University of Life Sciences, Faculty of Civil and Environmental Engineering, ul. Nowoursynowska 166, 02-787 Warszawa, Poland, e-mail: mieczyslaw_polonski@sggw.pl
} 


\section{INTRODUCTION}

The construction works are accompanied by an occurrence of various adverse events which sources are interrelated factors of, inter alia, technical, technological or organizational nature [1-4, 7-8, 1012, 14-15, 17-21, 26-30]. They contribute to schedule overruns and, consequently, deviations from the contractually agreed deadlines. Moreover, delays in the execution of works are associated with additional costs. Experience to date shows that this problem occurs frequently in the case of water and sewerage systems construction [22, 24-25]. When the delay is the fault of the investor, they can be obliged to pay compensation to the contractor. When the delay is due to the negligence of the contractor, they will be charged penalties for late completion of the works [5-6]. Every day of uncompensated work means additional costs for the contractor, which are associated with the maintenance of the construction site, employee remunerations (including the board), extension of the validity of the insurance policies, etc. In the case of water supply and sewerage facilities, there is another problem. People expect these investments, as they provide the basis for their living conditions improving. Any deviations from the planned course of the works cause public dispute and criticism. Therefore, the time management systems should be continually improved in each construction site. The aim this paper is to identify adverse events in the implementation of water supply and sewerage works, and to determine their effect with respect to the timing and the budget for the project. Recognition of this problem would provide the basis for an elaboration of an optimal model for work organization in companies performing such tasks. This can help to improve these enterprises productivity and, consequently, increase their competitiveness in the market.

\section{RESEARCH METHOD}

The basis for this paper is research conducted in 2010-2014 on the construction site of water supply and sewerage systems located in the provinces of Lower Silesia and Opole. The scope of construction works covered the water and sewerage systems with accompanying infrastructure, a water treatment plant and a sewage treatment plant. The study involved direct observation of the construction sites and a review of the construction documentation. Direct observations of the construction sites were carried out over a period of one year, from November 2011 to October 2012. Their aim was to identify the incidence and causes of stoppages on the sites. The research covered 12 construction sites. Observations included working teams composed of workers and machinery 
implementing the main technological processes. The most frequently performed works during the observation period on the relevant building sites were excavations and pipelines installation.

The research was performed using the shutter method. It involved an observer passing through the construction site at randomly chosen time intervals and recording whether work was being performed at the site, or if there was a work stoppage. In the event of the stoppage, the observer defined its cause. This method is recommended for determination of the locations of time lost on the construction sites $[9,16]$. The observations of the work time were accompanied by the review of the contract documents. The review consisted of a detailed analysis of the following documents: project documentation, agreement between the parties, schedule of works, quality of assurance programme, site registers, Records of Necessity, contractor's reports, interim payment certificates, minutes of coordination meetings, and correspondence between project participants. The overview referred to the documents created during the full cycle of construction.

\section{RESEARCH FINDINGS}

The direct observations on the construction site showed that work stoppages on the examined sites under were common. They accounted for $6 \%$ to $75 \%$ of all observations, $31 \%$ on average. Detailed data is shown in Table 1.

Table 1. Characteristics of the research sites covered by direct observations and a detailed overview of the construction documents

\begin{tabular}{|c|c|c|c|c|c|}
\hline $\begin{array}{l}\text { investments } \\
\text { indication }\end{array}$ & $\begin{array}{c}\text { contractual } \\
\text { completion time } \\
{[\text { month }]}\end{array}$ & $\begin{array}{c}\text { approved } \\
\text { contractual } \\
\text { amount } \\
\text { [PLN net] }\end{array}$ & $\begin{array}{c}\text { share of stoppages } \\
\text { in total number } \\
\text { of observations } \\
{[\%]}\end{array}$ & $\begin{array}{c}\text { exceeding } \\
\text { contractual time }{ }^{1} \\
{[\%]}\end{array}$ & $\begin{array}{c}\begin{array}{c}\text { exceeding } \\
\text { budget }^{2}\end{array} \\
{[\%]}\end{array}$ \\
\hline B1 & 10 & 1857636 & 8 & 11 & 0 \\
\hline B2 & 21 & 11279693 & 45 & 60 & 5 \\
\hline B3 & 21 & 2490000 & 39 & 0 & 0 \\
\hline B4 & 21 & 10352279 & 25 & 9 & 4 \\
\hline B5 & 10 & 8016393 & 75 & not completed & not completed \\
\hline B6 & 23 & 2845529 & 32 & 0 & 2 \\
\hline B7 & 20 & 5971408 & 37 & 45 & 3 \\
\hline B8 & 20 & 1459000 & 6 & 34 & 6 \\
\hline B9 & 21 & 4022000 & 50 & 25 & 1 \\
\hline $\mathrm{B} 10$ & 18 & 10333000 & 17 & 21 & 6 \\
\hline B11 & 20 & 6114506 & 8 & 19 & 4 \\
\hline B12 & 13 & 1962228 & 17 & 48 & 4 \\
\hline
\end{tabular}

\footnotetext{
${ }^{1}$ The percentage of the extended duration of investment in relation to the contractual completion time

${ }^{2}$ The percentage of the extended costs in relation to the contractual budget

Source: Own study based on direct research on the construction sites
} 
A detailed analysis of these passages causes allowed their classification into the following groups:

P1 - violation of work discipline,

P2 - adverse weather conditions,

P3 - faulty work organization,

P4 - incorrect assumptions in investment financing,

P5 - errors in the project documentation,

P6 - lack of investor supervision during the work,

P7 - others.

The sizes of the groups with respect to the total number of stoppages recorded are shown in Fig. 1.

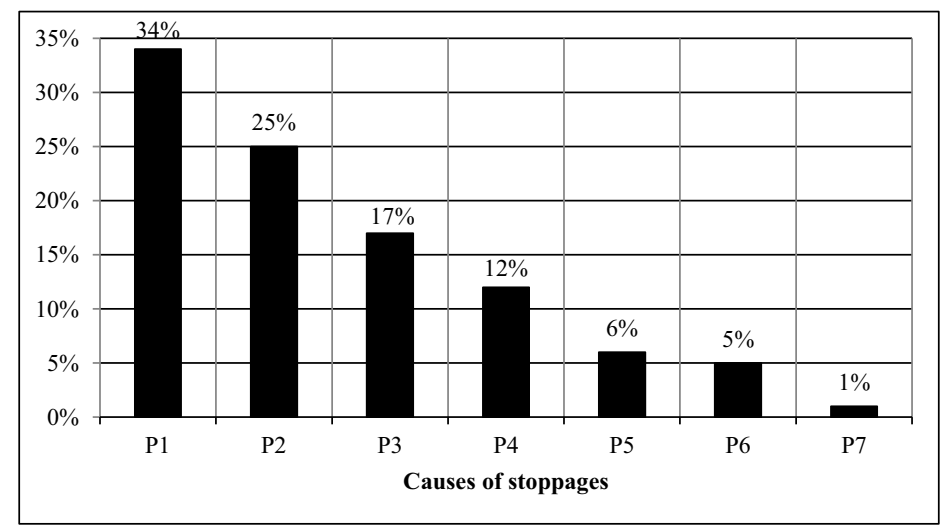

Fig. 1. Causes of stoppages on the research sites

Source: Own study based on direct research on the construction sites

Analysis of Fig.1 indicates that most of the work stoppages were caused by discipline violations by the production workers. These aspects are associated with the technical level and work organization, as well as the employee motivation system implemented in the company [13]. The observations pointed out that leaving the site without justification was clearly related to the specifics of water supply and sewerage works. The linear nature of the work means that construction sites are scattered and cannot be subject to the direct supervision of the management on a continuous basis. The research also revealed the situations when the employees were not provided with the right amount of information required to perform the work or the guidelines were not precise. Therefore, in companies engaged in water supply and sewerage works, particular attention should be paid to work teams supervising and to communication both with them and 
between them. This requires the adoption of an appropriate organizational structure, in which the authority of medium-ranked personnel should be strengthened.

The research conducted also points to the problem of adverse weather conditions in the construction of water and sewerage facilities. These works are always carried out in outdoors, and earthworks or assembly works which predominate here, are sensitive to high and low air temperatures and excessive precipitations [23]. However, the study shows that work discipline violations by the working teams constitute a greater problem than adverse weather conditions. This finding requires confirmation in further studies because the period of direct observation of the construction site was only one year of the full construction cycle of the object.

In order to recognize fully the causes of events which are the source of time losses and additional costs during the construction of water supply and sewerage systems, a review of the construction documents was conducted. The following constructions were selected for this purpose: B1, B10, $\mathrm{B} 11$ and $\mathrm{B} 12$.

The data presented in Table 1 indicate that, despite the fact that less than the average number of stoppages were noted on these construction sites in the course of field observations, time and cost overruns in their implementation were substantial. A detailed review of these investments documentation demonstrated that the events which contributed to this state were generated by factors of technical, technological and environmental character. They were classified into 8 groups:

D1 - improper preparation of the investment process,

D2 - calculation errors in the project documentation made by the designer,

D3 - conditions for realization other than those assumed in the project due to lack of inventory conducted by the designer before planning stage,

D4 - incorrect estimation of the amount of work in the bill of quantities,

D5 - non-optimal design solutions,

D6 - design solutions not meeting the requirements of the law,

D7 - execution of works non-compliant with project documentation,

D8 - difficult conditions for work execution.

This classification draws an attention to the large number of factors that are associated with faulty design of the work. The percentage shares of individual groups of the factors in additional construction costs generation are presented in Fig. 2. It shows that the problem of incorrect calculations of work amount on the bill of quantities was the most common in the case of the examined investments. Another factor, distinctive in terms of incidence, was that the conditions for 
works execution were different from those assumed in the project documentation. The incidence of other factors, identified on the basis of the construction documents, is clearly lower.

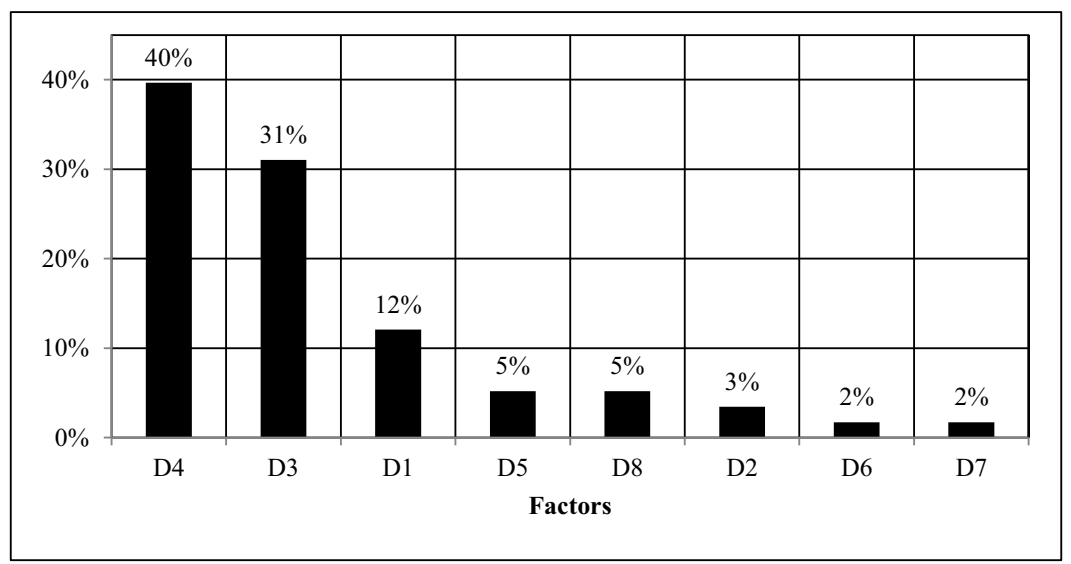

Fig. 2. The incidence of factors increasing costs of investment

Source: Own study based on a review of the construction documents

Fig. 3 shows the impact of events, which source factors were classified into groups D1 - D8, on the change to the investment costs. These costs are expressed as \% in relation to the contractual value of the works.

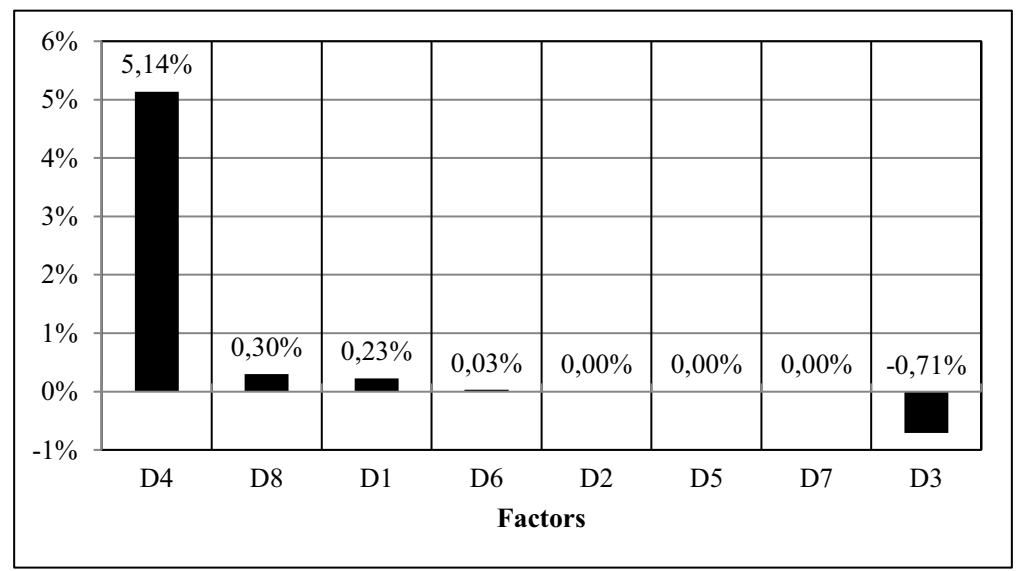

Fig. 3. The percentage of additional costs in the approved amount of the contract, resulting from factors D1 - D8

Source: Own study based on a review of the construction documents 
Fig. 3 indicates that in the case of the examined investments, additional work costs were mainly due to the wrong estimation of the amount of work at the designed site.

In order to obtain a total assessment, taking into account both the potential occurrence of events generating additional costs, and their magnitude, a diagram taking into account both these categories was drawn up (Fig. 4). The scale on the horizontal axis corresponds to the possibility of occurrence of factors D1 - D8, whereas the scale on the vertical axis represents the increase in investments costs resulting from factors D1 - D8. The location of factors D1 - D8 relative to these axis was determined on the basis of the data shown in Fig. 2 and 3.

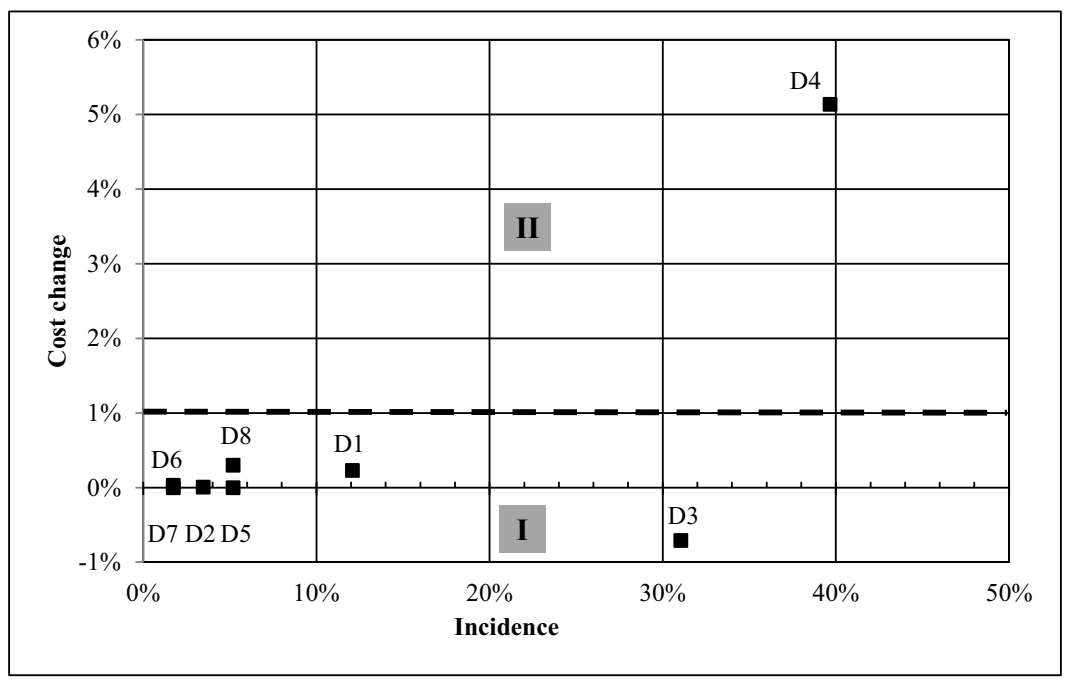

Fig.4 Occurrence of adverse events and their impact on the cost of the object's construction Source: Own study based on a review of the construction documents

It may be concluded from the above figure, that a portion of the adverse events identified on the basis of documentation review occurred rarely, and they influenced the increase in the investment cost to a lesser extent. The sources of these events were as follows: execution of works noncompliant with the solutions defined in the project documentation (D7) and mistakes made by designers in calculations or drawings (D2). In contrast, difficult conditions for works execution (D8) were noted with a low frequency, but their effect on additional cost of the project was already pronounced. Point D4 is in the farthest distance from the beginning of the coordinate system. This point represents a group of events related to wrong estimation of the required work amount. In accordance with the criteria adopted in this paper, this problem must be recognized as significant 
during the design and construction of water supply and sewerage systems. This means that most attention must be paid to the actions aimed at its elimination or minimization.

Two specific areas were specified on the diagram on the basis of points representing the causes and effects of adverse events. The events with a low incidence, the consequence of which is a loss not exceeding $1 \%$ of the budget allocated for the project, were assigned to area I. Area II is far less beneficial both to the contractor and the investor. It involves the events which occur relatively frequently, and result in significant additional costs.

The boundary between these areas is a dotted line. It was set at a level allowing for an increase in construction costs to $1 \%$. This level may be accepted by the participants in the investment process involving the construction of water supply and sewerage systems.

The results presented relate to only one type of investment. However, their primary advantage is that they were created on the basis of direct research conducted on construction site carried out under current organizational-technical and environmental conditions.

\section{SUMMARY}

The research and analysis conducted in the study showed that defects in project documentation are a serious problem, affecting time and costs of water supply and sewerage systems construction. Various factors are the sources of such defects. In the case of the examined investments, they mainly resulted from substandard work on the designer's part. They mainly consisted of incorrect calculations of work amount, and unreal assumptions in design due to lack of an inventory. These errors may have resulted from designer's inexperience. They may have also been the consequence of the "lowest price" principle as the factor determining designer selection.

The analyses performed in the study demonstrated that in case of significant/strategic investments such as water supply and sewerage systems, the possibility of error occurrence in the project should be definitely limited. Irrespective of this, errors and mistakes always happen. This paper attempts to determine a tolerable limit for the frequency of their occurrence and their effect on the investment budget. These limits constitute the reserves of $1 \%$ of the value of the contractual amount.

The results presented in this paper enable to determine the probability of the occurrence of adverse events typical for water supply and sewerage systems projects, and their impact on the course of implementation. These are two dimensions allowing to create the matrix of risk assessment. It allows to create the plan of action, and to indicate the actions aimed at time and financial risks minimizing for such projects. 


\section{REFERENCES}

1. F. K. Adams, "Construction Contract Risk Management: A study a practices in the United Kingdom", Cost Engineering, Vol. 50, No. 1: 22-33, 2008.

2. A. Al-Selwi, J. Przybylski, „Ekonomiczno-matematyczny model oceny projektu z uwzględnieniem ryzyka”, Przegląd Budowlany, 4/2006: 42-44, 2006.

3. M. Chester, C. Hendrickson, "Cost impacts, scheduling impacts, and claims process during construction", Journal of Construction Engineering and Management, January: 102-107, 2005.

4. P. K. Dey, "Project Risk Management: A Combined Analytic Hierarchy Process and Decision Tree Approach", Cost Engineering, Vol. 44, No. 3: 13-26, 2002.

5. Fidic: Warunki Kontraktowe dla budowy dla robót inżynieryjno - budowlanych projektowanych przez zamawiającego. Edycja: 4. wydanie angielsko-polskie niezmienione 2008 (tłumaczenie 1. wydania 1999). Warszawa: Sidir, 2008

6. Fidic: Warunki Kontraktowe dla urządzeń oraz projektowania i budowy. Edycja: 4. wydanie angielsko-polskie niezmienione 2008 z erratą ( thumaczenie 1. wydania 1999). Warszawa: Sidir, 2008.

7. M. Gierczak, „Wybrane zdarzenia niepożądane w technologii horyzontalnych przewiertów sterowanych (HDD)", Instal, nr 3: 67-71, 2014.

8. B. Grzyl, „Praktyczne aspekty zarządzania ryzykiem inwestora w toku przygotowania inwestycji budowlanej”, Strategie zarządzania ryzykiem w przedsiębiorstwie - komunikacja ryzyka TNOIK, 2011: 196-208, 2011.

9. B. Hoła, J. Mrozowicz, „Modelowanie procesów budowlanych o charakterze losowym”, Wrocław, Dolnośląskie Wydawnictwo Edukacyjne, 2003.

10. M. Jaśkowski, G. Biruk, „Ocena porównawcza mierników odporności harmonogramów budowlanych. Budownictwo i Inżynieria Środowiska, vol. 2, nr 4: 501-505, 2011.

11. O. Kapliński (red.)., „Metoda i modele badań w inżynierii przedsięwzięć budowlanych. Studia z zakresu Inżynierii”, nr 57, Warszawa: PAN, KILiW, IPPT, 2007.

12. R. Kozik, E. Starzyk, „Czynniki utrudniające działalność na rynku budowlanym”, Prace Naukowe Instytutu Budownictwa Politechniki Wrocławskiej. Studia i Materiały, vol. 91, nr 20: 97-104, 2008.

13. L. Kozioł, R. Pyrek „Model systemu zarządzania czasem pracy w przedsiębiorstwie”, Zeszyty Naukowe Małopolskiej Wyższej Szkoły Ekonomicznej w Tarnowie Nr 2 (13)/2009 T. 2, 2009.

14. A. Kristowski, „Bezpieczeństwo planowania procesu budowy z uwzględnieniem ryzyka, niepewności i zakłóceń”, Przegląd Budowlany, 4/2005: 48-50, 2005.

15. R. Marcinkowski, A. Kopeć, „Ocena ryzyka czasu i kosztów w planowaniu produkcji budowlanej”, Przegląd Budowlany, 7-8/2008: 70-75, 2008.

16. Z. Mikołajczyk, „Techniki organizatorskie w rozwiązywaniu problemów zarządzania”, Warszawa: Wydawnictwo Naukowe PWN, 2002.

17. Z. Milan, „Wybrane metody oceny ryzyka niedotrzymania terminów realizacji budowy”, Przegląd Budowlany, 12/2005: 30-35, 2005.

18. A. Minasowicz, „Analiza ryzyka w projektowaniu przedsięwzięcia budowlanego”, Warszawa: Oficyna Wydawnicza Politechniki Warszawskiej, 2008.

19. A. Minasowicz, B. Kostrzewa, „Analiza czasowo-kosztowa planowanego przedsięwzięcia budowlanego przy zastosowaniu zbiorów rozmytych”, Budownictwo i Inżynieria Środowiska, vol. 2, nr 4: 595-604, 2011.

20. M. Połoński, „Bezpieczeństwo organizacyjne realizacji inwestycji budowlanych”, Strategie zarządzania ryzykiem w przedsiębiorstwie - zarządzanie ryzykiem projektu TNOiK, 2007: 333-342, 2007.

21. M. Rogalska, Z. Hejducki, „Zastosowanie buforów czasu w harmonogramowaniu procesów budowlanych”, Przegląd Budowlany, 6/2005: 36-42, 2005.

22. I. Rybka, "Wpływ zmian w dokumentacji projektowej na koszt i czas robót budowlanych", W T. M. Traczewska (red.), Interdyscyplinarne zagadnienia w inżynierii i ochronie środowiska 2, pp. 435-443, Wrocław: Oficyna Wydawnicza Politechniki Wrocławskiej, 2012.

23. I. Rybka, E. Bondar-Nowakowska, "Weather conditions as a risk factor in sewage system constructions", Infrastruktura i Ekologia Terenów Wiejskich, 12/2011: 39-48, 2011.

24. I. Rybka, E. Bondar-Nowakowska, "Zmiany w dokumentacji projektowej a ryzyko Zamawiającego", Archiwum Instytutu Inżynierii Lądowej, 13/2012: 305-310, 2012.

25. I. Rybka, E. Bondar-Nowakowska, "Planning of the risk handling methods related to alterations to project documentation” Procedia Engineering, Modern Building Materials, Structures and Techniques, 57: 952-952, 2013.

26. D. Skorupka, „Planowanie przedsięwzięć budowlanych z uwzględnieniem warunków ryzyka”, Strategie zarządzania ryzykiem w przedsiębiorstwie - ryzyko a bezpieczeństwo organizacji TNOiK, 2004: 451-458, 2004 . 
27. D. Skorupka, „Metoda ilościowej oceny ryzyka realizacji przedsięwzięć budowlanych”, Przegląd Budowlany, 7-8/2006: 66-70, 2006.

28. A. Warszawski, R. Sacks, „Practical multifactor approach to evaluating risk of investment in engineering projects", Journal of Construction Engineering and Management, May/June: 354-367, 2004.

29. A. Więckowski, “Analiza czasu dysponowanego zmiany roboczej”, Przegląd Budowlany, 1/2007: 38-42, 2007.

30. S. Zapłata, "Wewnętrzne czynniki wpływające na rezultaty zarządzania jakością w przedsiębiorstwach budowlanych”, Przegląd Budowlany, 12/2006: 45-48, 2006.

Received 22. 06. 2015

Revised 03. 09. 2015

\section{LIST OF FIGURES AND TABLES:}

Tab. 1. Characteristics of the research objects covered by direct observations of the construction sites and a detailed overview of the construction documents

Tab. 1. Charakterystyka obiektów objętych bezpośrednimi obserwacjami terenowymi oraz szczegółowym przeglądem dokumentów

Fig. 1. Causes of stoppages on the objects of research

Rys. 1. Przyczyny przerw w pracy na obiektach badawczych

Fig. 2. The incidence of factors increasing costs of investment

Rys. 2. Częstość występowania czynników wzrostu kosztów realizacji inwestycji

Fig. 3. Impact of events generated by factors D1 - D8 on change of investment costs

Rys. 3. Wpływ zdarzeń generowanych przez czynniki D1 - D8 na wzrost kosztów inwestycji

Fig. 4. Occurrence of adverse events and their impact on the cost of the object's construction

Rys. 4. Występowanie zdarzeń niepożądanych i ich wpływ na wzrost kosztów realizacji obiektu 


\section{PRZYCZYNY ORAZ SKUTKI ZDARZEŃ NIEPOŻĄDANYCH NA BUDOWACH SYSTEMÓW WODOCIĄGOWYCH I KANALIZACYJNYCH}

Keywords: systemy wodociagowe, systemy kanalizacyjne, przerwy w robotach budowlanych

\section{STRESZCZENIE:}

W latach 2010-2014 na dwunastu budowach wodociągowych i kanalizacyjnych, realizowanych na terenie województw dolnośląskiego i opolskiego, przeprowadzono badania które miały na celu identyfikację zdarzeń niepożądanych. W przypadku większości rozpatrywanych inwestycji zarówno termin zakończenia inwestycji jak i budżet określony w kontrakcie były przekroczone. Przeprowadzone badania stanowiły podstawę do oceny wpływu zidentyfikowanych zdarzeń na czas trwania i koszt inwestycji.

Badania polegały na bezpośredniej obserwacji stanowisk roboczych oraz obejmowały przegląd dokumentacji budowy. Obserwacje terenowe wykonano metodą migawkową w okresie jednego roku. W czasie ich prowadzenia, na rozpatrywanych budowach, wykonywane były głównie wykopy oraz montaż rurociągów.

Obserwacje stanowisk pracy wykazały, że na poszczególnych budowach, przerwy w pracy występowały ze zróżnicowaną częstością. Stanowiły one od 6 do $75 \%$ obserwacji. Główną przyczyną stwierdzonych przerw było naruszanie dyscypliny pracy przez pracowników produkcyjnych - 34\% oraz niekorzystne warunki pogodowe - 25\%.

Analiza polegająca na porównaniu ilości przerw, zaobserwowanych na rozpatrywanych budowach z terminami zakończenia tych inwestycji wykazała na brak zależności w tym zakresie. Obiekty, na których stwierdzono stosunkowo dużą liczbę przerw, ukończone zostały w zaplanowanym terminie. Natomiast w przypadku obiektów, gdzie liczba przerw była mniejsza niż przeciętna, przekroczenie czasu i kosztów ich realizacji było znaczne. W celu wyjaśnienia tego stanu przeprowadzony został szczegółowy przegląd zapisów dokonanych w dziennikach budowy, protokołach konieczności oraz w raportach wykonawcy. Przegląd ten dotyczył dokumentów powstałych w pełnym cyklu budowy, czterech inwestycji.

Zidentyfikowane na podstawie dokumentów przyczyny strat czasu oraz dodatkowych kosztów zostały zakwalifikowane do ośmiu grup. Podstawę tego podziału stanowiły źródła powstania strat. Ocena wpływu poszczególnych grup na przedłużenie terminu zakończenia oraz na dodatkowe koszty realizacji wykazała, że w przypadku rozpatrywanych inwestycji najsilniejsze oddziaływanie wykazały błędy występujące w dokumentacjach projektowych. Polegały one głównie na niewłaściwym obliczeniu ilości robót do wykonania - 40\% oraz przyjęciu do projektowania innych warunków niż występujące w rzeczywistości - 31\%. Przeprowadzona analiza wskazała również na problem niewłaściwego przygotowania procesu inwestycyjnego - $12 \%$.

Błędy i zaniedbania na etapie przygotowywania dokumentacji projektowych występują często. W związku z tym, w pracy podjęto próbę wyznaczenia tolerowanej granicy strat generowanych przez te czynniki. Granica ta powinna wyznaczać wielkość rezerwy finansowej, którą powinien dysponować inwestor.

Wyniki przeprowadzonej analizy wskazują, że w przypadku rozpatrywanych inwestycji rezerwa ta mogłaby kształtować się na poziomie $1 \%$ wartości kwoty kontraktowej gdyby nie problem błędów występujących w przedmiarach robót. Czynnik ten był dominującym zarówno pod względem częstości występowania jak i wpływu na ostateczny koszt robót. Zgodnie z przyjętymi w pracy kryteriami problem błędnego szacowania ilości robót do wykonania należy uznać, jako istotny w projektowaniu oraz wykonawstwie robót wodociągowych i kanalizacyjnych. Oznacza to, że działaniom na rzecz jego wyeliminowania lub minimalizacji należy poświęcić jak najwięcej uwagi. 
Przedstawione w pracy wyniki umożliwiają określenie prawdopodobieństwa wystąpienia zdarzeń niepożądanych, typowych dla przedsięwzięć wodociągowych i kanalizacyjnych oraz ich wpływu na przebieg realizacji inwestycji. Wiedza na temat wielkości tych czynników pozwala na opracowanie macierzy oceny ryzyka. Narzędzie to stanowi podstawę do opracowanie planu postępowania oraz do wskazania działań, których celem jest minimalizacja zagrożeń czasowych i finansowych dla tego rodzaju przedsięwzięć. 